University of Rhode Island

DigitalCommons@URI

Past Departments Faculty Publications (CELS) College of the Environment and Life Sciences

1991

\title{
Behavioral Analysis of the Escape Response in the Juvenile Lobster Homarus Americanus Over the Molt Cycle
}

S. I. Cromarty

J. Stanley Cobb

University of Rhode Island

Gabriele Kass-Simon

Follow this and additional works at: https://digitalcommons.uri.edu/cels_past_depts_facpubs

Terms of Use

All rights reserved under copyright.

\section{Citation/Publisher Attribution}

Cromarty, S. I., Cobb, J. S., \& Kass-Simon, G. (1991). Behavioral Analysis of the Escape Response in the Juvenile Lobster Homarus Americanus Over the Molt Cycle. J. Exp. Bio., 158, 565-581. Retrieved from http://jeb.biologists.org/content/158/1/565.

Available at: http://jeb.biologists.org/content/158/1/565

This Article is brought to you for free and open access by the College of the Environment and Life Sciences at DigitalCommons@URI. It has been accepted for inclusion in Past Departments Faculty Publications (CELS) by an authorized administrator of DigitalCommons@URI. For more information, please contact digitalcommonsgroup@uri.edu. 


\title{
BEHAVIORAL ANALYSIS OF THE ESCAPE RESPONSE IN THE JUVENILE LOBSTER HOMARUS AMERICANUS OVER THE MOLT CYCLE
}

\author{
BY S. I. CROMARTY, J. S. COBB AND G. KASS-SIMON* \\ Department of Zoology, University of Rhode Island, Biological Sciences \\ Building, Kingston, RI 02881, USA
}

Accepted 25 March 1991

\begin{abstract}
Summary
1. Components of the escape response of the American lobster were compared over the molt cycle. Number of tailflips, frequency, duration and distance were measured. Velocity, acceleration, force and work were computed from the above measurements, using time-lapse video-recordings of escaping lobsters.

2. Soft-shelled postmolt lobsters (stage B) traveled further, spent more time tailflipping and performed a larger number of tailflips than hard-shelled premolt lobsters (stage D). Hard-shelled lobsters had a more forceful initial power swim, achieved a higher overall velocity and acceleration and, therefore, produced more forceful swims with greater energy expenditure (measured by work output) than soft-shelled animals.

3. Among hard-shelled lobsters, velocity, acceleration, force and work fell off markedly in the latter part of their subsequent swims as a consequence of the prolonged duration and reduced frequency of these swims. Soft-shelled lobsters sustained their swimming velocity, acceleration, force and work for their entire subsequent swimming response.

4. There are likely to be large molt-related differences in energy metabolism, endocrinology and nerve and muscle physiology which lead to the observed differences in the escape response.
\end{abstract}

\section{Introduction}

Throughout their lives, decapod crustaceans undergo periodic molting to accommodate growth and regeneration (Drach, 1939). Over the course of the molt cycle, metabolic, neuroendocrine and neurophysiological changes occur (Knowles and Carlisle, 1956; Passano, 1960; Kleinhölz and Keller, 1979; Quakenbush, 1986); these are reflected not only in the physical appearance of the animal but also in the emergence of distinct patterns of behavior that are characteristic of the given molt stage.

* To whom reprint requests should be sent.

Tey words: escape response, molt cycle, behavioral analysis, tailflips, Homarus americanus. 
As early as 1880 , Huxley noted that immediately after the molt, lobsters appeared 'timid'. Much later, Scrivener (1971) described aggressive behavior in adult lobsters. In the American lobster, Tamm and Cobb (1978) discovered that, in the early postmolt stages (A and B), the probability of occurrence of the escape response increases. In contrast, the frequency of aggressive behavior, in particular the meral spread, increases during mid-premolt stages (D1 and D2). These behavioral changes are not unique to lobsters; molt-related changes in aggressive behavior have also been described in stomatopods (Steger and Caldwell, 1983).

Lobsters are likely to be most vulnerable to predation immediately after molting when they are soft-shelled. At that time, they do not respond to threat with aggressive behaviour but try to escape instead (Atema and Cobb, 1980). Experiments by Lang et al. (1977) show that the escape response occurs more often in juveniles and small adults than in larger adults. Large animals are more likely to respond to a threat with an aggressive behavioral posture (the meral spread). According to Lang et al. (1977) as an animal grows, the escape behavior is gradually replaced with defensive or aggressive behavior. The tail flipping behavior becomes less effective as an instrument of escape for two reasons. (1) The conduction time of medial giant impulses that travel from the brain to the sixth abdominal ganglion is increased dramatically as the animal grows, resulting in an increased latency for the escape response; (2) the ratio of abdomen length to carapace length decreases from 2 to 1.4 from the first larval stage to the adult. The abdominal flexing muscles must therefore propel an increasing amount of body mass (mostly claws) through the water during an escape sequence.

The perception that hard- and soft-shelled lobsters have different probabilities of responding to a threat with a meral spread or with escape swimming suggests that there may also be subtle differences in the characteristics of these responses for animals of different molt stages.

To look into this possibility, we videotaped escaping lobsters of different molt stages and analyzed various components of the escape response. We compared distance, duration, velocity and acceleration of the escape response, as well as the number and frequency of tailflips and the force and work done during the response.

\section{Materials and methods}

Juvenile American lobsters Homarus americanus (26-35 mm carapace length) were obtained from the Environmental Protection Agency, Narragansett, Rhode Island. Lobsters were hatched from five females between 20 and 29 July 1988. During the experiments, from May to September 1989, animals were housed at the Narragansett Bay Campus of the University of Rhode Island. Animals were held in separate but connecting tanks in a circulating heated seawater system, maintained at $19-20^{\circ} \mathrm{C}$ under a $14 \mathrm{~h} / 10 \mathrm{~h}$ light/dark cycle.

The animals were fed daily on a mixed diet of blue mussels Mytilus edulis and green crabs Carcinus maenas, alternated with freeze-dried shrimps. $20-30 \mathrm{~h}$ pric 
to an experiment, the animals were moved to the Kingston campus of the university, where they were placed in separate tanks $\left(30 \mathrm{~cm}^{3}\right)$, each with individual recirculating sea water. Lobsters were also isolated visually from each other. Animals were then fed once with freeze-dried shrimps, $24 \mathrm{~h}$ prior to the experiment. Three hours prior to an experiment, male lobsters, whose claws and antennae were intact, were placed in the experimental tank and left undisturbed. One hour before the experiment, the physical condition of each animal was checked. Animals were used only once and only if they moved around the tank and/or exhibited antennule flicking.

Experiments were run between 12:00 and 17:00 $\mathrm{h}$ in an aquarium filled with filtered recirculated sea water from Narragansett Bay, which was replaced biweekly. Four consecutive experiments were performed before the water was changed. Water temperature was maintained at $19-20^{\circ} \mathrm{C}$ by a cooling unit (Frigid Units, AE-234 AG-602). Salinity ranged between 26 and $33 \%$. There were no statistical differences in escape behavior among experiments conducted either at different experimental times [ANOVA, $F(3,22)=0.869, P>0.05$ ] or a different number of days after water replacement [ANOVA, $F(3,32)=0.342, P>0.05$ ].

The experimental area consisted of an open-ended tank $(1.0 \mathrm{~m}$ long $\times 0.3 \mathrm{~m}$ wide $\times 0.3 \mathrm{~m}$ high $)$, immersed into the larger main tank $(2.2 \mathrm{mlong} \times 0.75 \mathrm{~m}$ wide $\times 0.91 \mathrm{~m}$ high). A weighted wooden screen with a pulley provided a blind at the side of the experimental tank. A mirror fastened into a rectangular wooden box attached to a $0.5 \mathrm{~m}$ long dowel provided the stimulus. An experiment began whenever a lobster approached the screen at the end of the 1-h acclimation period.

The stimulus was lowered by hand at the front of the main tank at an approximate angle of $45^{\circ}$ at the same time that the wooden screen was raised. With this method we were unfailingly able to evoke an escape response. The mirror by itself probably did not exert an effect since, in a number of subsequent trials without the mirror, an escape response could still be elicited. However, we do know that, in preliminary trials, when a number of other objects were substituted for the stimulus described above, none of them reliably elicited an escape response. Some of the trial objects used included adult American lobsters, jets of salt water, air bubbles and a tautog.

A Sony Camcorder and a Panasonic WV-CD20 camera were placed in horizontal and vertical positions, respectively. The experiments were simultaneously recorded on two video-recording systems (Panasonic AG-6010 and Panasonic NV-8950). Video-recordings of each lobster were analyzed frame-byframe ( $66.67 \mathrm{~ms}$ per frame). In order to measure distance traveled, a metric grid divided into $0.5 \mathrm{~cm}$ units was painted onto the side of the experimental tank. Transparent overlays on the video monitor were later used to mark the distance swum by a given animal. Distance traveled along the length of the tank, for each lobster, was measured by using the position of the tip of the rostrum as a landmark. Time was automatically recorded on the videotape and numbers of tailflips were counted in subsequent reviewing of the recordings. An independent bserver inspected all recordings and rejected runs in which the experimental 
parameters were not strictly adhered to (e.g. cases in which the stimulus assembly was presented at the incorrect angle or advanced more than $10 \mathrm{~cm}$ into the tank).

After each experiment, the animal's molt stage was determined by examining cuticular changes and setal development in the pleopods (Aiken, 1973). Since animals become progressively harder after ecdysis (stage E), it is also possible to determine molt periods by testing various carapace areas for rigidity (Aiken, 1980). Experimental animals were placed in the following categories: stage C (intermolt); stages D0, D1, D2 or D3 (premolt); postmolt lobsters, stage A up to $48 \mathrm{~h}$ following ecdysis and stage B from 48 to $96 \mathrm{~h}$ after ecdysis.

An escape response consists of two types of tailflips (Wine and Krasne, 1972, 1982): an initial power swim followed by numerous subsequent swims (from 5 to 15 in our experiments). A tailflip or swim is defined in this study as beginning immediately after the start of abdominal flexion and ending at abdominal extension.

The following characteristics of the escape response were analyzed for each lobster: distance $(\mathrm{cm})$, duration (s), velocity $\left(\mathrm{m} \mathrm{s}^{-1}\right)$, acceleration $\left(\mathrm{m} \mathrm{s}^{-2}\right)$, number of tailflips, frequency (tailflips $\mathrm{s}^{-1}$ ), relative activity (tailflips $\mathrm{m}^{-1}$ ), force (mass $\times$ acceleration) and work (force $\times$ distance). In evaluating acceleration, the addedmass forces (Batchelor, 1967) which act on accelerating bodies in fluids were ignored since these are a simple multiple of mass. [Added-mass $=\alpha_{x} p V \mathrm{~d} U_{\mathrm{x}} / \mathrm{d} t$, where $\alpha_{x}$ represents the added-mass coefficient of body orientation in the $x$ direction, $\rho$ is the density of water, $U_{\mathrm{x}}$ is the instantaneous velocity of the body, $V$ is the volume and $t$ is time (Daniel and Meyhöfer, 1989).] We have found in our animals that the mass to volume ratio was $1.12 \pm 0.04$ (mean \pm s.D., $N=10$ ) and that volume varied linearly with mass. In addition, the variance of mass was very small. Their mass in grams was $13.42 \pm 2.61$ (mean \pm s. D., $N=36$ ). This would cause $\alpha_{\mathrm{x}}$ to have little effect in our calculated values for different molt stages. Another variable that we did not include in our calculations was body rotation. There was only slight body rotation during swimming in our experiments and this was not measurable by our methods. Since these factors $\left(\alpha_{\mathrm{x}}\right.$ and $\left.V\right)$ were not incorporated into the measurements, the data reflect relative differences across the molt stages rather than absolute performance values. In addition, four animals whose gross swimming pattern deviated from a rectilinear motion were discarded.

Each of the parameters were analyzed for (1) the entire escape response sequence, (2) the initial power swim, (3) the subsequent swims over the entire subsequent swimming distance and (4) the subsequent swims in each half of that distance. Since in preliminary experiments it became apparent that there were differences in the distance traveled by various lobsters, we divided the distance traveled in the subsequent swims by half and analyzed each half.

\section{Statistical analysis}

Values for each molt stage were obtained from a sample of nine animals in each stage giving a total of 36 animals. All of the substages of D (D0-D4) were collapsed into a single stage. D stage lobsters consisted of six D0 and three D 
substages. A fixed analysis of variance (ANOVA) with a post hoc Tukey test and a modified Bonferroni correction was used to compare means of the six planned comparisons. Values were considered significant at $P<0.05$, or at $P<0.025$ with the Bonferroni correction (Keppel, 1982). A multiple analysis of variance (MANOVA) with a one-way repeated measures follow-up test was used when comparing the first to the second half of the subsequent swims. A MANOVA with a number of single one-way ANOVA follow-up tests was used when comparing each half of the subsequent swims across the molt stages. A Geisser-Greenhouse correction factor was used if the parameter in question was influenced by a prior occurrence. The subsequent swims are influenced by the initial power swim. If there was already a single degree of freedom, the Geisser-Greenhouse factor was not used. Values were considered significant at $P<0.05$. Square brackets indicate that only those molt stages are significantly different.

ANOVAs, MANOVA and Tukey tests were run on SPSSX software (SPSSX Inc., Chicago) on the University of Rhode Island mainframe computer (IBM 370). Repeated-measure and one-way ANOVA follow-up tests were calculated by hand.

\section{Results}

Weight

There were no significant differences in the weights of lobsters over the four molt stages [ANOVA, $F(3,32)=1.537, P>0.05]$. Weights and standard deviations, in grams, for each stage were: A, $12.00 \pm 1.22 ; \mathrm{B}, 14.42 \pm 3.09 ; \mathrm{C}, 13.31 \pm 2.21$; , $13.94 \pm 3.17$.

\section{Behavior}

A summary of significant data for all parameters is presented in Table 1.

\section{Distance, duration, velocity and acceleration}

Distance $(\mathrm{cm})$. Stage B lobsters swam further than animals in the other three stages $[\mathrm{B}>\mathrm{A}=\mathrm{C}=\mathrm{D}$; ANOVA, $F(3,32)=11.96, P<0.025]$ (Fig. 1). This was due to a difference in the subsequent swimming distance, since the distances covered by the initial power swims were not significantly different from one another across the molt cycle [ANOVA, $F(3,32)=2.18, P>0.05$ ].

Duration ( $s$ ). The escape response of stage $\mathrm{B}$ animals lasted significantly longer than that of the other stages [B $>\mathrm{A}=\mathrm{C}=\mathrm{D}$; ANOVA, $F(3,32)=16.87, P<0.025$ ] (Fig. 2). The difference in durations of the escape response was due to the significantly shorter duration of the initial power swim of stage $D$ lobsters $[\mathrm{D}<\mathrm{A}=\mathrm{B}=\mathrm{C}$; ANOVA, $F(3,32)=12.06, P<0.025]$ and the significantly longer duration of subsequent swimming of stage $\mathrm{B}$ animals $[\mathrm{B}>\mathrm{A}=\mathrm{C}=\mathrm{D}$; MANOVA $F(1,32)=234.13, P<0.05]$. If the distance covered by the subsequent swims is divided in half for each animal, and the time taken to cover the first half is compared to the time taken to cover the second half, a significant difference is cound among the four molt stages. Stage $\mathrm{C}$ and D animals take longer to traverse 


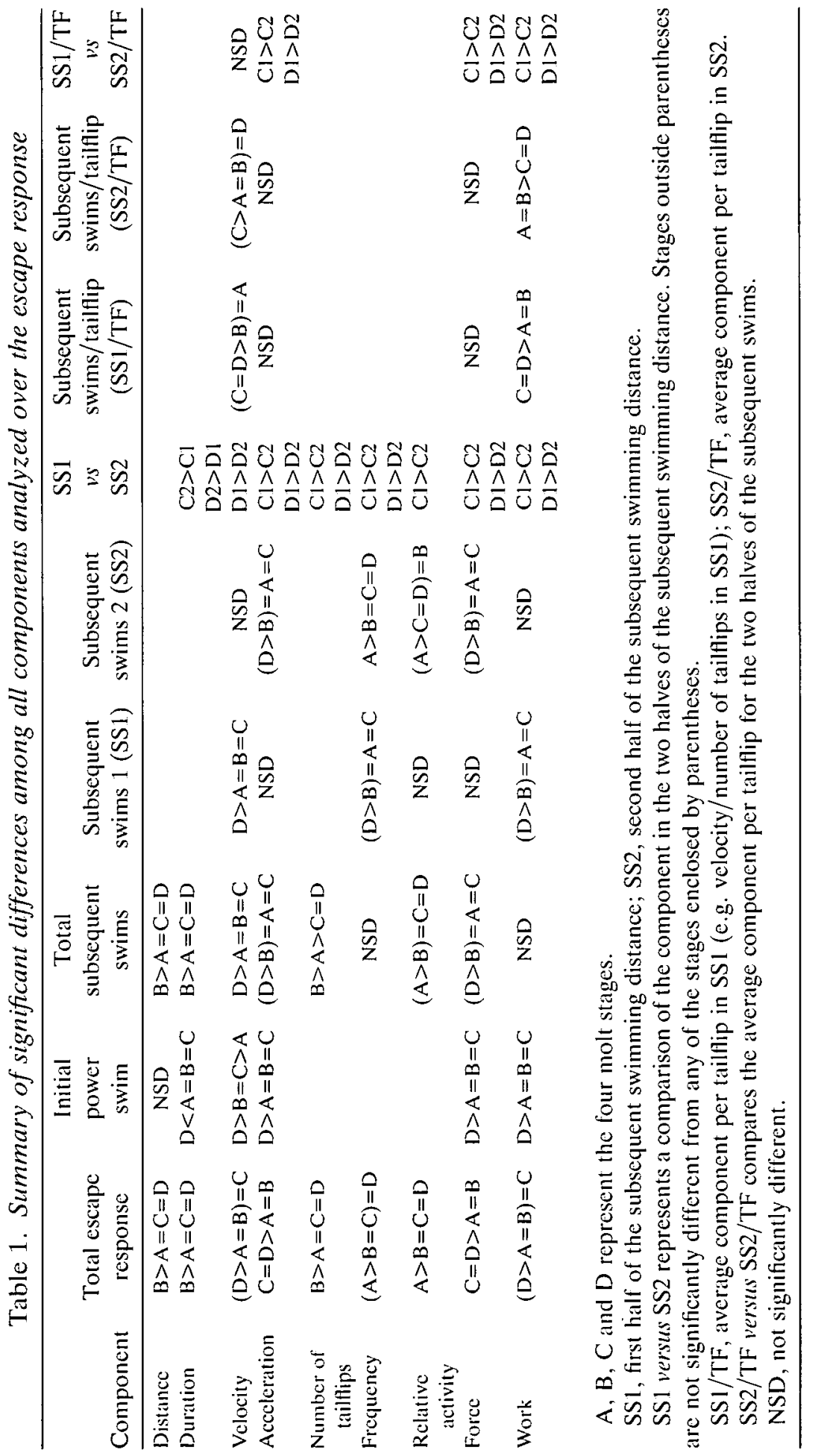



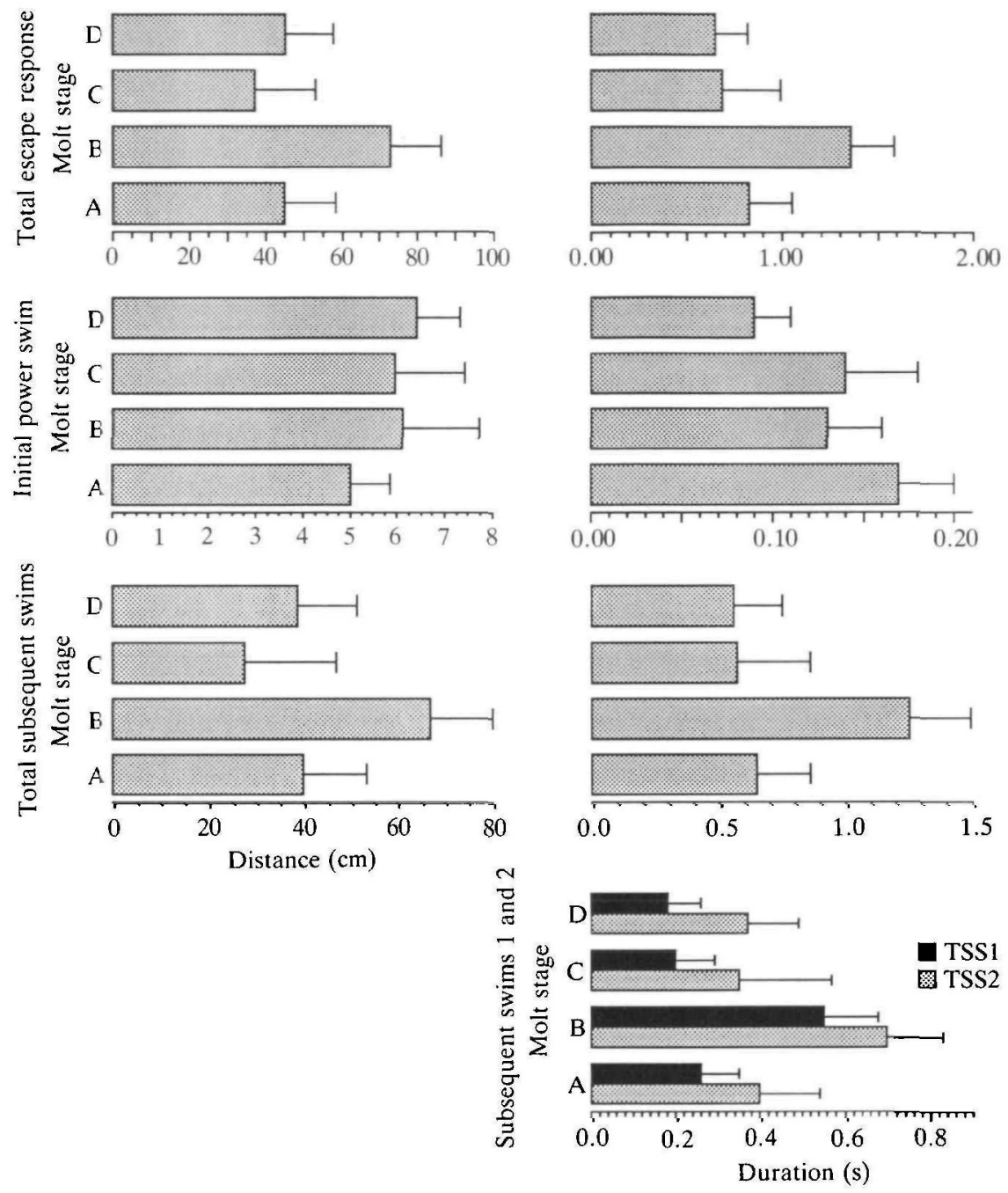

Fig. 1. Distance traveled and duration of the escape response over the molt cycle. TSS1 and TSS2 are the times spent tailflipping in the first and second halves of the subsequent swims. Bars indicate standard deviations. No data for distance for the two halves of the subsequent swims exist because of experimental design.

the second half of their subsequent swimming distance than they do to cover the first half $[\mathrm{C} 2>\mathrm{C} 1$ and D2 $>\mathrm{D} 1$; MANOVA, $F(1,32)=66.54, P<0.05]$.

Velocity $\left(\mathrm{ms}^{-1}\right)$. Stage $\mathrm{D}$ animals achieved a significantly greater velocity than either stage $A$ or stage $B$ animals; the velocity of stage $C$ animals was not statistically different from that of the other three stages $\{[D>A=B]=C$; ANOVA, $F(3,32)=3.91, P<0.025\}$ (Fig. 2). This difference in speed was due to the significantly greater velocity of both the initial power swim and the subsequent imming of stage D lobsters. In addition, while the velocity of the initial power 

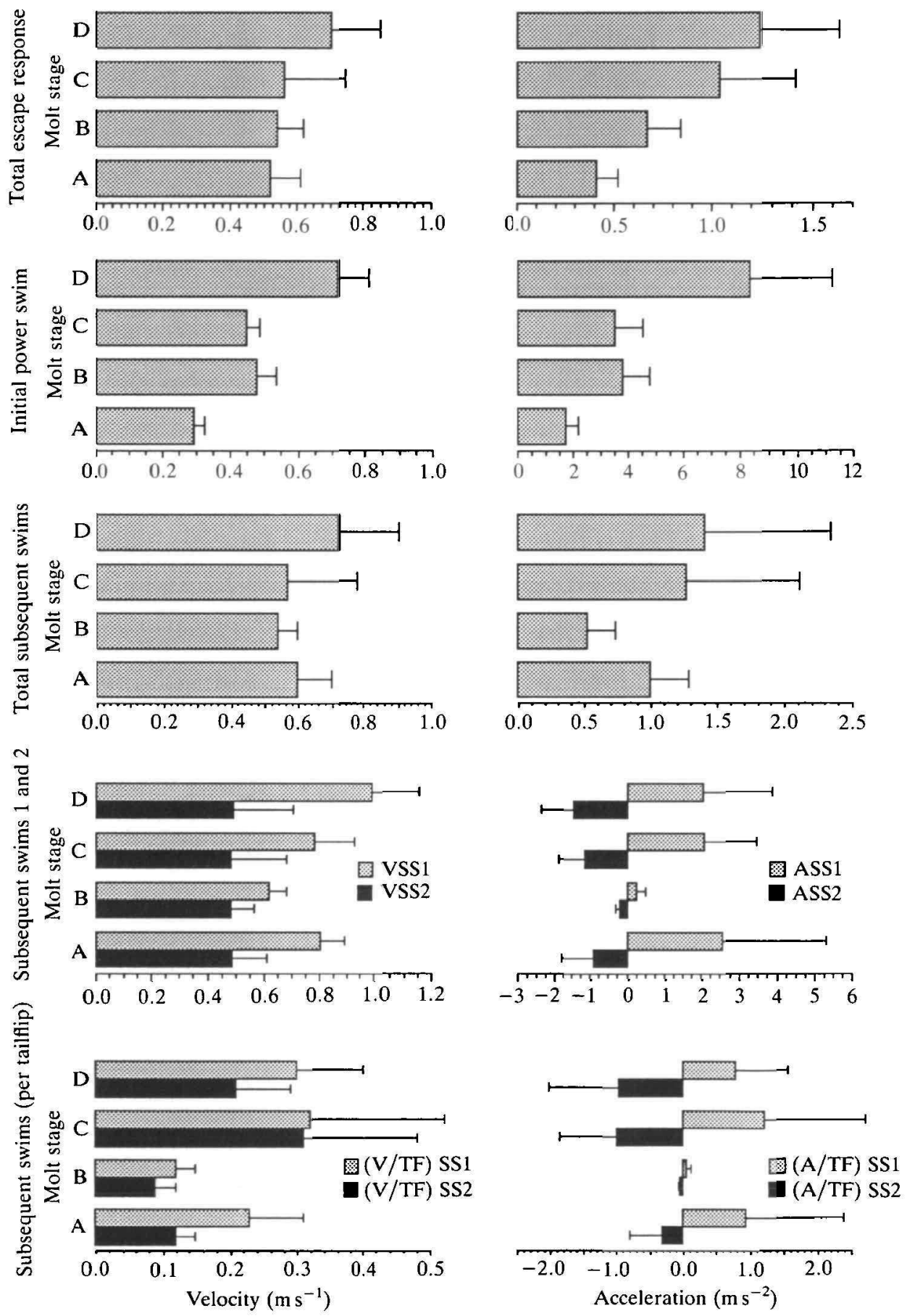

Fig. 2 
Fig. 2. Velocity and acceleration of the escape response over the molt cycle. VSS1 and VSS2, velocities in the first and second halves of the subsequent swims. ASS1 and ASS2, accelerations in the first and second halves of the subsequent swims. (V/TF) SS1 and (V/TF) SS2, average velocities per tailflip in the first and second halves of the subsequent swims. (A/TF) SS1 and (A/TF) SS2, average acceleration per tailflip for the first and second halves of the subsequent swims.

swim of stage $D$ lobsters was significantly higher, that of stage $A$ lobsters was significantly lower $[\mathrm{D}>\mathrm{B}=\mathrm{C}>\mathrm{A}$; ANOVA, $F(3,32)=74.86, P<0.025]$. In the subsequent swims, stage $D$ lobsters were significantly faster than lobsters in the other three stages $[\mathrm{D}>\mathrm{A}=\mathrm{B}=\mathrm{C}$; MANOVA, $F(1,32)=6.24, P<0.05]$. This was due to a significant difference in the first half, but not in the second half, of the subsequent swimming distance $[\mathrm{D}>\mathrm{A}=\mathrm{B}=\mathrm{C} ;$ MANOVA, $F(3,32)=11.19$, $P<0.05)$.

A comparison between the velocity achieved in the first half with that achieved in the second half of the swimming distance of each molt stage revealed that there was a significant drop in velocity among stage $\mathrm{D}$ lobsters in the second half of the swimming distance. There was no significant difference in the drop-off in velocity between the first and second halves of the other three stages [D1>D2; MANOVA, $F(1,32)=110.60 ; P<0.05]$.

The mean velocity of individual tailflips during the subsequent swims was calculated by dividing the velocity of each half of the subsequent swimming distance by the number of tailflips in that half. The velocity of an individual tailflip of stage $B$ animals in the first half of the subsequent swims was significantly less than that of either stage $C$ or stage $D$ animals. That of stage $A$ animals was not significantly different from that of animals in any of the other three molt stages $[(\mathrm{C}=\mathrm{D}>\mathrm{B})=\mathrm{A}$; MANOVA, $F(1,32)=9.83, P<0.05]$. In the second half of the subsequent swims, the velocity of each tailflip of stage $C$ animals was greater than those of either A or B stages; that of stage D animals was not significantly different from that of animals in the other three stages. There was no significant difference in the velocities of individual tailflips between the first and second halves of the swimming distances of any of the molt stages.

Acceleration $\left(\mathrm{m} \mathrm{s}^{-2}\right)$. The overall acceleration of animals of both stages $\mathrm{C}$ and $D$ was greater than that of animals in either stages $A$ and $B[C=D>A=B$; ANOVA, $F(3,32)=14.48, P<0.025$ ] (Fig. 2). The initial power swim of stage $D$ animals produced a significantly greater acceleration than that of the other three stages, which were not significantly different from one another $[D>A=B=C$; ANOVA, $F(3,32)=27.52, P<0.025]$. In the subsequent swims, stage $\mathrm{D}$ lobsters were significantly faster than stage $B$ lobsters $\{[D>B]=A=C$; MANOVA, $F(1,32)=28.24, P<0.05\}$. This was due to a significant difference in the second half, but not in the first half, of the subsequent swimming distance $\{[\mathrm{D}>\mathrm{B}]=\mathrm{A}=\mathrm{C} ;$ MANOVA, $F(1,32)=92.41, P<0.05\}$.

A comparison between the acceleration achieved in the first half with that hieved in the second half of the subsequent swims of each molt stage revealed 
that there was a significant drop in acceleration among stage $C$ and $D$ lobsters in the second half of the swimming distance $[\mathrm{C} 1>\mathrm{C} 2, \mathrm{D} 1>\mathrm{D} 2$; MANOVA, $F(1,32)=92.41, P>0.05]$.

The mean acceleration of individual tailflips during the subsequent swims was calculated by dividing the acceleration of each half of the subsequent swimming distance by the number of tailflips in that half. The acceleration of an individual tailflip in both halves for each molt stage was not significantly different between stage $C$ and $D$ lobsters. Individual tailflips of stage $C$ and $D$ lobsters decelerated significantly in the second half of the subsequent swims $[C 1>C 2, D 1>D 2$; MANOVA, $F(1,32)=20.91, P<0.05]$.

\section{Number of tailfips, frequency and relative activity}

Number of tailfips. Stage B lobsters produced significantly more tailflips after the initial power swim than stage $A$ lobsters, which, in turn, produced more than the other two stages [B $>\mathrm{A}>\mathrm{C}=\mathrm{D}$; ANOVA, $F(3,32)=14.38, P<0.025]$ (Fig. 3).

Both stage $C$ and stage $D$ lobsters performed significantly fewer swims in the second half of the swimming distance than in the first half; the differences for stages $\mathrm{A}$ and $\mathrm{B}$ were not significant $[\mathrm{C} 1>\mathrm{C} 2, \mathrm{D} 1>\mathrm{D} 2$; MANOVA, $F(1,32)=8.34$, $P<0.05]$.
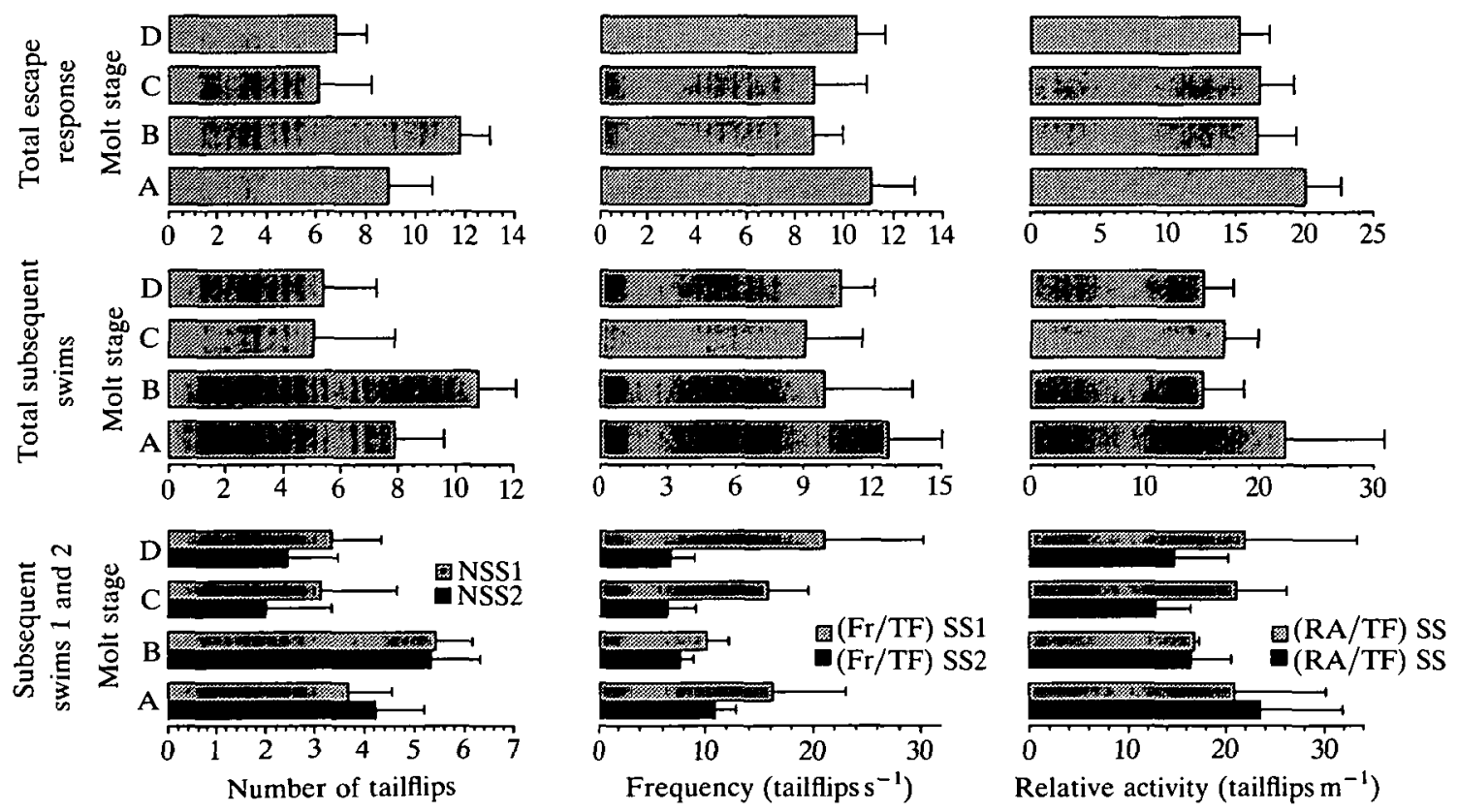

Fig. 3. Number and frequency of tailflips and relative activity of the escape response over the molt cycle. NSS1 and NSS2, numbers of tailflips in the first and second halves of the subsequent swims. ( $\mathrm{Fr} / \mathrm{TF}$ ) SS1 and (Fr/TF) SS2, average frequencies per tailflip in the first and second halves of the subsequent swims. (RA/TF) SS1 and (RA/TF) SS2, average relative activity per tailflip in the first and second halves of the subsequent swims. 
Frequency (tailfips $\mathrm{s}^{-1}$ ). Stage A lobsters produced significantly more tailflips per second than either stage B or stage C lobsters; the swimming frequency of stage $D$ lobsters was not significantly different from that of the other three stages $\{[\mathrm{A}>\mathrm{B}=\mathrm{C}]=\mathrm{D}$; ANOVA, $F(3,32)=4.82, P<0.025\}$ (Fig. 3). In the first half of the subsequent swims, the frequency of tailflips of stage $D$ lobsters was double that of stage $B$ lobsters. Frequencies for stage $A$ and $C$ animals were not significantly different from frequencies for the other stages $\{[D>B]=A=C$; MANOVA, $F(1,32)=48.90, P<0.05\}$. In the second half of the swims, stage $\mathrm{A}$ lobsters had a significantly higher frequency than the other molt stages $[A>B=C=D$; MANOVA, $F(1,32)=48.90, P<0.05]$. There was a significant decrease in the swimming frequency of stage $\mathrm{C}$ and $\mathrm{D}$ animals between the first and second halves of the subsequent swimming distance $[\mathrm{C} 1>\mathrm{C} 2, \mathrm{D} 1>\mathrm{D} 2$; MANOVA, $F(1,32)=48.90, P<0.05]$.

Relative activity (tailfips $\mathrm{m}^{-1}$ ). The numbers of swim taken to cover the escape distances were significantly different for lobsters of the four stages; stage A animals performed significantly more swims than those of the other three stages $[\mathrm{A}>\mathrm{B}=\mathrm{C}=\mathrm{D}$; ANOVA, $F(3,32)=5.75, P<0.025$ ] (Fig. 3).

In the first half of the subsequent swims, no stages were significantly different, but in the second half stage A animals performed a greater number of swims per meter than stage $C$ and $D$ animals. Relative activity of stage $B$ lobsters did not differ from that of the other three molt stages [ $(A>C=D)=B$; MANOVA, $F(1,32)=10.81, P<0.05]$.

The number of swims per meter taken by stage $C$ animals to traverse the first half of the swimming distance was significantly greater than the number taken to cover the second half of the distance. Although stage D animals also appeared to show a decrease in the number of swims in the second half, the differences between the two halves were not significant for any of the other three stages $[\mathrm{C} 1>\mathrm{C} 2$; MANOVA, $F(1,32)=10.81, P<0.05]$.

\section{Force and work}

Force (mass $\times$ acceleration). There was a significant difference in the overall average force exerted by the animals of the four molt stages; both premolt and intermolt lobsters swam with a greater force than lobsters in stages $\mathrm{A}$ and $\mathrm{B}$ $[\mathrm{C}=\mathrm{D}>\mathrm{A}=\mathrm{B}$; ANOVA, $F(3,32)=13.81, P<0.025]$ (Fig. 4). Stage D lobsters exerted more than twice as much force during the initial power swim than lobsters in the other three stages; the difference is significant $[\mathrm{D}>\mathrm{A}=\mathrm{B}=\mathrm{C}$; ANOVA; $F(3,32)=13.83, P<0.025]$. During the subsequent swims, stage $\mathrm{D}$ lobsters swam more forcefully overall than stage $B$ lobsters $\{[D>B]=A=C$; MANOVA; $F(1,32)=59.57, P<0.05\}$, although in the first half of their subsequent swimming distance, there were no significant differences in force. In the second half, stage $D$ lobsters exerted more force than stage $B$ lobsters, but stages $A$ and $C$ were not significantly different from stages $B$ or $D\{[D>B]=A=C$; MANOVA; $F(1,32)=9.61, P<0.05\}$. There was a significant decrease in force produced for Dth $\mathrm{C}$ and $\mathrm{D}$ stage lobsters in the second half of the subsequent swims $[\mathrm{C} 1>\mathrm{C} 2$, 

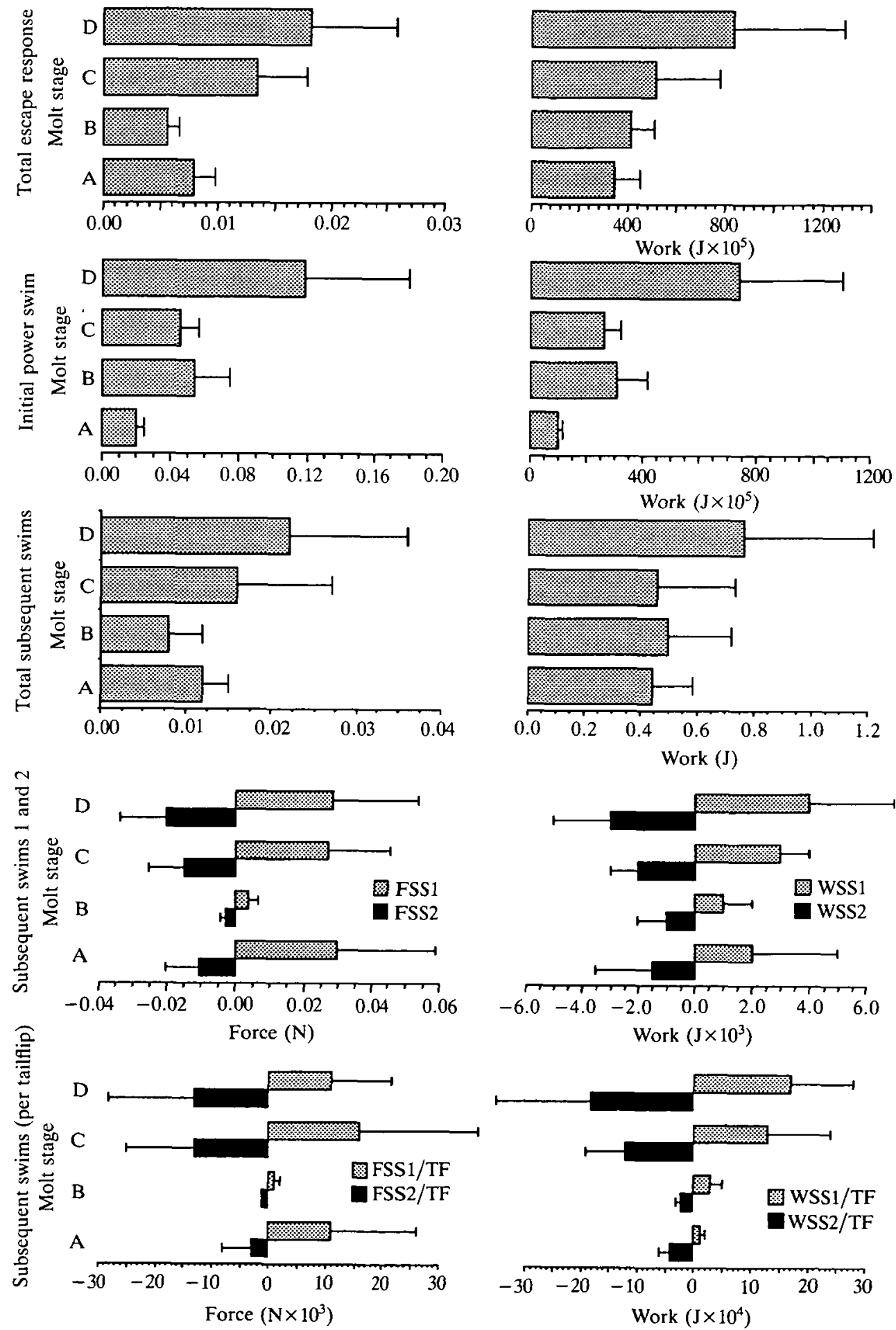

Work $\left(\mathrm{J} \times 10^{5}\right)$
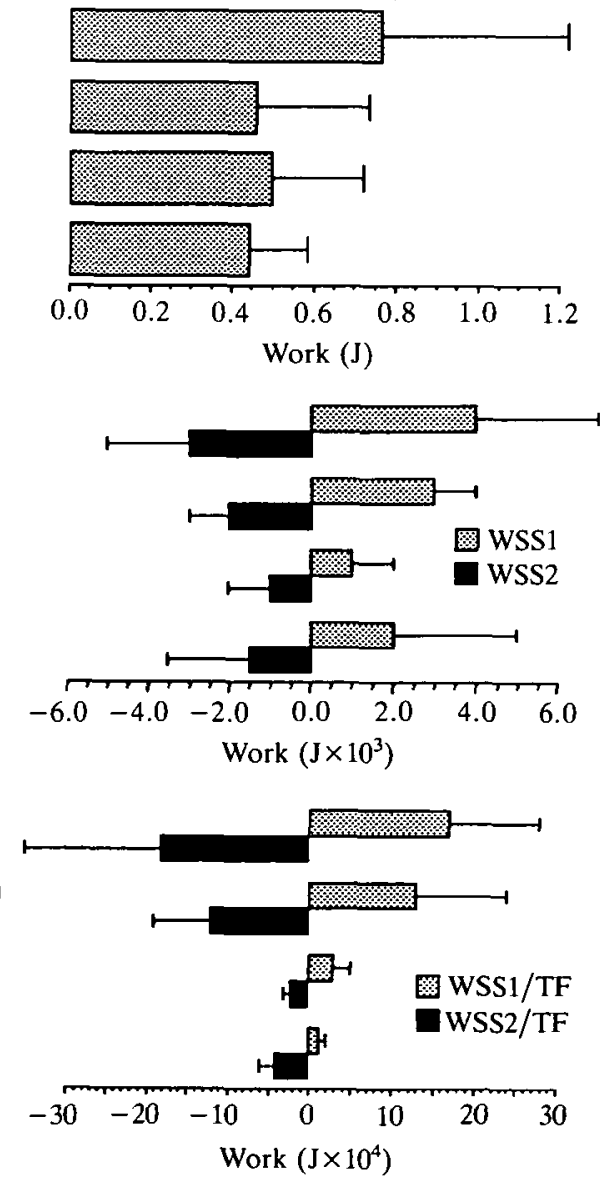

Fig. 4 
Fig. 4. Force and work of the escape response over the molt cycle. FSS1 and FSS2, force in the first and second halves of the subsequent swims. WSS1 and WSS2, work in the first and second halves of the subsequent swims. FSS1/TF and FSS2/TF, average force per tailflip in the first and second halves of the subsequent swims. WSS1/TF and WSS2/TF, average work per tailflip in the first and second halves of the subsequent swims.

D1 $>$ D2; MANOVA; $F(1,32)=9.61, P<0.05]$. The mean forces exerted by a single swim during the first and second halves of the swimming distance were not significant; however, a comparison between the halves in each stage revealed that there was a significant decrease in force produced by each swim for both stage $\mathrm{C}$ and D lobsters [C1>C2, D1 $>$ D2; MANOVA, $F(1,32)=20.42, P<0.05]$.

Work (force $\times$ distance). Over the entire escape response, stage $\mathrm{D}$ lobsters did more work than either stage $A$ or stage $B$ lobsters $\{[D>A=B]=C$; ANOVA, $F(3,32)=5.68, P<0.025\}$ (Fig. 4). Work performed by stage $\mathrm{D}$ lobsters during the initial power swim was significantly greater than that of the other three stages $[\mathrm{D}>\mathrm{A}=\mathrm{B}=\mathrm{C}$; ANOVA, $F(3,32)=18.52, P<0.025]$.

During the subsequent swims, no differences were found among the molt stages. In the first half of their subsequent swimming distance, stage $D$ animals did more work than stage $B$ lobsters; the work done by other stages was not significantly different $\{[\mathrm{D}>\mathrm{B}]=\mathrm{A}=\mathrm{C}$ MANOVA; $F(1,32)=51.30, P<0.05\}$. There was a significant decrease in work produced for both stage $C$ and stage $D$ lobsters in the second half of their swimming distance $[\mathrm{C} 1>\mathrm{C} 2, \mathrm{D} 1>\mathrm{D} 2$; MANOVA, $F(1,32)=51.30, P<0.05]$. The mean work exerted by a single swim during the first half of the swims was greater for stage $C$ and $D$ animals, while in the second half stage $A$ and $B$ animals did the greater amount of work. Stages $C$ and $D$ thus show a dramatic decrease in work performed $[\mathrm{C} 1>\mathrm{C} 2, \mathrm{D} 1>\mathrm{D} 2$; MANOVA, $F(1,32)=56.88, P<0.05]$.

\section{Discussion}

Molting does not occur as a short-lived, isolated event in the crustacean life cycle; rather, it represents a prolonged process involving the entire physiology of the animal. Typically, $70 \%$ of the time between molts is spent in preparation for, and then recovery from, ecdysis (Drach, 1939). Metabolism, endocrinology, reproduction and behavior are altered either directly or indirectly over the molt cycle (Passano, 1960; Skinner, 1966a,b, 1985; Stevenson, 1972; Aiken, 1969, 1980; Chang and Bruce, 1981; Chang, 1985; see Quakenbush, 1986, for a review; Kravitz, 1988). Water content and fluid absorption, and ionic, protein and blood sugar concentrations have been examined in various crustaceans and were found to vary over the molt cycle (Lowndes and Panikkar, 1941; Robertson, 1960; Glynn, 1968; Telford, 1968; Barlow and Ridgway, 1969; Hepper, 1977; Mykles, 1979, 1980). There are also significant molt-related differences in electrical mroperties at the neuromuscular junction (Schwanke et al. 1990), as well as 
differences in blood composition (Fadool et al. 1988, 1989; Mercaldo-Allen, 1989, 1990) and levels of ecdysone (Adelung, 1969; Faux et al. 1969; Stevenson et al. 1979; Hopkins, 1983, 1986).

Behavioral changes in the molt stages have been observed in Homarus americanus (Herrick, 1909; Cobb and Tamm, 1975; Tamm and Cobb, 1978; Atema et al. 1979). Directly after the molt, the exoskeleton, or armor, is soft. Crustaceans at this time are vulnerable to injury, predation and cannibalism (Reaka, 1975, 1976; Tamm and Cobb, 1976; Sastry and Ehinger, 1980). Defensive behaviors exist and are similar in many crustacean species. Panulirus argus, immediately before and directly after the molt, were submissive and regularly tailflipped when approached by conspecifics (Lipcius and Herrnkind, 1982). Timidness patterns have also been observed in Panulirus cygnus (Thomas, 1966), Homarus gammarus (Elmhirst, 1923), Pachygrapsus crassipes (Hiatt, 1948) and various stomatopods (Reaka, 1975; Steger and Caldwall, 1983). Defensive behaviors have also been documented in a large number of genera in brachyuran crabs (Schöne, 1968).

We have now shown that when juvenile American lobsters, Homarus americanus, are induced to exhibit the escape behavior in several molt stages, characteristic differences in this behavior occur with respect to molt stage.

Soft-shelled, postmolt lobsters (stage B) travel further, produce more tailflips and swim longer, at a sustained velocity, than do premolt lobsters. The swimming frequency and the relative activity of the earliest molts (stage A) are also significantly higher. All of these factors, together with an increased propensity to swim in response to a threat, tend to compensate for the slower initial power swim and the only average force and acceleration of the subsequent swims among softshelled animals. Presumably, the decreased force produced by soft-shelled lobsters is a result in the change of muscle composition (Skinner, 1962, 1966a,b) and the rigidity of the exoskeleton (Aiken, 1980). These escape differences correlate with the increase in activity and submissiveness seen in other postmolt crustaceans.

Although there are differences in the rigidity of the exoskeleton between softand hard-shelled lobsters, which in turn might affect their hydrodynamic efficiency, the distances traveled by animals in the different molt stages during the initial power swim were not significantly different; postulated differences in propulsive efficiency, therefore, cannot be addressed.

In contrast to post-molt animals, hard-shelled, premolt lobsters, which are more likely to respond to threats with a meral spread rather than escape swimming (Tamm and Cobb, 1978), have a quick, forceful initial power swim, followed by subsequent swims that rapidly decrease in velocity, acceleration, force and work. These latter characteristics are also shared by intermolt lobsters. As a consequence of the greater force of their initial power swim and subsequent swims, premolt lobsters perform more work during an escape than do their soft-shelled counterparts. The force produced by intermolt lobsters is smaller in the initial power swim, but because of the force in the first half of the subsequent swims, the total work they do is not significantly different from that of premolt animals. 
Without field studies, it is not possible to say which is the more effective defense; the frequently used meral spread of premolt lobsters coupled with a fast and short, but difficult to evoke, escape response or the easily evoked, slower but longer-lasting and sustained escape swimming of post-molt animals, coupled with an infrequently used meral spread. Quite possibly, it will turn out that each type of response is most appropriate for the physical condition of an animal in the given molt stage and that the differences in response have developed to be maximally effective for that stage, i.e. the most effective defense for soft-shelled lobsters is to escape, the most effective defense for hard-shelled lobsters is to attack. In this regard, premolt lobsters work harder during the escape response with a concomitantly greater energy expenditure, particularly in the initial power swim. This might, in part, account for its less frequent use as a defensive strategy by hardshelled lobsters.

As our results indicate, there appear to be significant differences in the characteristics of the escape behavior over the molt cycle. This, together with the many other molt-related differences in physiology, emphasizes the necessity of taking molt stages into account in all analyses of crustacean behavior and physiology.

In any event, the differences in the characteristics of the escape behavior over the molt cycle underscore the all-encompassing nature of molting and the farreaching changes that take place in energy metabolism, endocrinology and nerve and muscle physiology of an animal that molts.

\section{References}

Adelung, D. (1969). Die Ausschüttung and Funktion von Häutungshormon während eines Zwischenhäutungsintervalls bein der Strandkrabbe Carcinus maenas L.Z. Naturforsch 24B, 1447-1455.

Aiken, D. E. (1969). Photoperiod, endocrinology and the crustacean molt cycle. Science 164, $149-154$.

Aiken, D. E. (1973). Proecdysis, setal development, and molt prediction in the American lobster (Homarus americanus). J. Fish. Res. Bd Can. 30, 1337-1344.

AIKEN, D. E. (1980). Molting and growth. In The biology and Management of Lobsters, vol. 1 (ed. J. S. Cobb and B. F. Phillips), pp. 91-163. New York: Academic Press.

ATEMA, J. AND CoBB, J. S. (1980). Social behavior. In The Biology and Management of Lobsters, vol. 1 (ed. J. S. Cobb and B. F. Phillips), pp. 409-450. New York: Academic Press.

atema, J., Jacobsen, S., Karnofsky, E., Olesko-Szuts, S. and Stein, L. (1979). Pair formation in the lobster, Homarus americanus: Behavioral development, pheromones and mating. Mar. Behav. Physiol. 6, 277-296.

Barlow, J. AND Ridgway, G. J. (1969). Changes in serum protein during the molt and reproductive cycles of the American lobster (Homarus americanus). J. Fish. Res. Bd Can. 26, 2101-2109.

Batchelor, G. K. (1967). An Introduction to Fluid Dynamics. London: Cambridge University Press.

Chang, E. S. (1985). Hormonal control of molting in decapod crustacea. Am. Zool. 25, $179-185$.

Chang, E. S. And Bruce, M. J. (1981). Ecdysteroid titers of larval lobster. Comp. Biochem. Physiol. 70A, 239-241.

CobB, J. S. AND Tamm, G. R. (1975). Dominance status and molt order in lobsters (Homarus americanus). Mar. Behav. Physiol. 3, 119-124. 
Daniel, T. L. AND MeYhöfer, E. (1989). Size limits in escape locomotion of carridean shrimp. J. exp. Biol. 143, 245-265.

Drach, P. (1939). Mue et cycle d'intermue chez les crustacés décapodes. Annls Inst. Océanogr. Monaco 19, 103-392.

Elmhirst, R. (1923). On the moulting of the lobster. Proc. R. physiol. Soc., Edinburgh 20, 271-276.

Fadool, D. A., Brown, P. R., Совв, J. S. and Kass-Simon, G. (1989). HPLC analysis of lobster haemolymph over the molt cycle. Comp. Biochem. Physiol. 93C, 225-230.

Fadool, D. A., CobB, J. S., Kass-Simon, G. and Brown, P. R. (1988). Liquid chromatographic procedures for the analysis of compounds in the serotonergic and octopamine pathways of lobster hemolymph. J. Chromatogr. 452, 491-501.

Faux, A., Horn, D. H. S., Middleton, E. J., Fales, H. M. and Lowe, M. E. (1969). Moulting hormones of a crab during ecdysis. Chem. Commun. 1969, 175-176.

GlynN, J. P. (1968). Studies on the ionic, protein, and phosphate changes associated with the molt cycle of Homarus vulgaris. Comp. Biochem. Physiol. 26, 937-946.

Hepper, B. T. (1977). Changes in blood serum protein levels during the moulting cycle of the lobster, Homarus gammarus (L.). J. exp. mar. Biol. Ecol. 28, 293-296.

Herrick, F. H. (1909). Natural history of the American lobster. Bull. U.S. Bur. Fish. 29, 149-408.

Hiat, R. W. (1948). The biology of the lined shore crab, Pachygrapsus crassipes Randall. Pacif. Sci. 2, 135-213.

Hopkins, P. M. (1983). Patterns of serum ecdysteroids during induced and uninduced proecdysis in the fiddler crab. Uca pugilator. Gen. comp. Endocr. 52, 350-356.

Hopkins, P. M. (1986). Ecdysteroid titers and Y-organ activity during late anecdysis and proecdysis in the fiddler crab, Uca pugilator. Gen. comp. Endocr. 63, 362-373.

HuXley, T. H. (1880). An Introduction to the Study of Zoology, Illustrated by the Crayfish. New York: D. Appleton and Co. (Reissued by MIT Press, 1974).

Keppel, G. (1982). Design and Analysis: A Researcher's Handbook. 2nd edn. New Jersey: Prentice Hall Inc.

KleinhölZ, L. H. AND Keller, R. (1979). Endocrine regulation in Crustacea. In Hormones and Evolution (ed. E. J. W. Barrington), pp. 159-214. New York: Academic Press.

Knowles, F. G. W. and Carlisle, D. B. (1956). Endocrine control in the Crustacea. Biol. Rev. 31, 396-473.

Kravitz, E. A. (1988). Hormonal control of behavior: Amines and the biasing of behavioral output in lobsters. Science 241, 1775-1781.

Lang, F., Govind, C. K., Costello, W. J. and Greene, S. I. (1977). Developmental neuroethology: Changes in escape and defensive behavior during growth of the lobster. Science 197, 682-684.

Lipcius, R. N. ANd Herrnkind, W. F. (1982). Molt cycle alterations in behavior, feeding and diel rhythms of a decapod crustacean, the spiny lobster Panulirus argus. Mar. Biol. 68, 241-252.

Lowndes, A. G. and PanikKar, N. K. (1941). A note on the changes in water content of the lobster (Homarus vulgaris M.-Edw.) during moult. J. mar. biol. Ass. U.K. 25, 111-112.

Mercaldo-Allen, R. (1989). Changes in the blood chemistry of the American lobster, Homarus americanus, over the molt cycle. Proceedings of a Workshop (Life History of the American Lobster), pp. 25a. Orono, Maine: Lobster Institute.

Mercaldo-Allen, R. (1990). Changes in the blood chemistry of the American lobster, Homarus americanus, over the molt cycle. Masters thesis, Southern Connecticut State University. pp. 1-152.

Mykles, D. L. (1979). The mechanism of fluid absorption at ecdysis in the American lobster, Homarus americanus and $H$. gammarus, and Dungeness crab, Cancer magister. PhD thesis, University of California, Berkeley.

Mykles, D. L. (1980). The mechanism of fluid absorption at ecdysis in the American lobster, Homarus americanus. J. exp. Biol. 84, 89-101.

Passano, L. M. (1960). Molting and its control. In The Physiology of Crustacea, vol. 1 (ed. T. H. Waterman), pp. 473-536. New York: Academic Press. 
Quackenbush, L. S. (1986). Crustacean endocrinology, a review. Can. J. Fish. aquat. Sci. 43, 2271-2282.

REAKA, M. L. (1975). Molting in stomatopod crustaceans. I. Stage of the molt cycle, setagenesis, and morphology. J. Morph. 146, 55-80.

RAEKA, M. L. (1976). Lunar and tidal periodicity of molting and reproduction in stomatopod Crustacea: a selfish herd hypothesis. Biol. Bull. mar. biol. Lab., Woods Hole 150, 468-490.

Robertson, J. D. (1960). Ionic regulation in the crab Carcinus maenas (L.) in relation to the moulting cycle. Comp. Biochem. Physiol. 1, 183-212.

Sastry, A. N. And Ehinger, R. E. (1980). Dominance hierarchies among communally held juvenile lobsters, Homarus americanus. Mar. Behav. Physiol. 7, 85-93.

Schöne, H. (1968). Agonistic and sexual display in aquatic and semi-terrestrial brachyuran crabs. Am. Zool. 8, 641-654.

Schwanke, M. L., Совв, J. S. and Kass-Simon, G. (1990). Synaptic plasticity and humoral modulation of neuromuscular transmission in the lobster claw opener muscle during the molt cycle. Comp. Biochem. Physiol. 97C, 143-149.

Scrivener, J. C. E. (1971). Agonistic behavior of the American lobster, Homarus americanus (Milne-Edwards). Fish. Res. Bd Can. Tech. Rep. 235, 1-128.

SKINNER, D. M. (1962). The structure and metabolism of a crustacean integumentary tissue during a molt cycle. Biol. Bull. mar. biol. Lab., Woods Hole 123, 635-647.

SKINNER, D. M. (1966a). Breakdown and reformation of somatic muscle during the molt cycle of the land crab, Geocarcinus lateralis. J. exp. Zool. 163, 115-124.

SKINNER, D. M. (1966b). Macromolecular changes associated with the growth of crustacean tissues. Am. Zool. 6, 235-242.

SKINNER, D. M. (1985). Interacting factors in the control of the crustacean molt cycle. Am. Zool. 25, 275-284.

STEger, R. AND CALDWEll, R. L. (1983). Intraspecific deception by bluffing: a defense strategy of newly moulted stomatopods (Arthropoda: Crustacea). Science 221, 558-560.

Stevenson, J. R. (1972). Changing activities of the crustacean epidermis during the moulting cycle. Am. Zool. 12, 373-380.

Stevenson, J. R., Armstrong, P. W., Chang, E. S. and O'Connor, J. D. (1979). Ecdysone titers during the molt cycle of the crayfish Orconectes sanborni. Gen. comp. Endocr. 39, $20-25$.

TAMm, G. R. AND CoBb, J. S. (1976). Diel ecdysis rhythms in juvenile lobsters Homarus americanus. J. Fish. Res. Bd Can. 33, 819-821.

TAMm, G. R. AND CoBB, J. S. (1978). Behavior and the crustacean molt cycle: Changes in aggression of Homarus americanus. Science 200, 79-81.

TELFORD, M. (1968). Changes in blood sugar composition during the molt cycle of the lobster, Homarus americanus. Comp. Biochem. Physiol. 26, 917-926.

Tномаs, L. R. (1966). Moulting behavior of the Western Australian crayfish Panulirus cygnus George (Decapod Reptantia). Crustaceana 11, 111-112.

Wine, J. J. AND KRASNE, F. B. (1972). The organization of escape behavior in the crayfish. J. exp. Biol. 56, 1-18.

WiNE, J. J. AND KRASNE, F. B. (1982). The cellular organization of crayfish escape behavior. In The Biology of Crustacean Neurobiology: Structure and Function, vol. 3 (ed. D. E. Bliss), pp. 241-292. New York: Academic Press. 
